\title{
HUBUNGAN TAYANGAN IMAJINATIF DENGAN POLA KOMUNIKASI PADA ANAK USIA PRASEKOLAH DITAMAN KANAK KANAK RIYANTI BTN TAMARUNANG KABUPATEN GOWA
}

\author{
Oleh: Audah Mannan \& Rustiakhil Hukmi \\ Fakultas Dakwah dan Komunikasi \\ Universitas Islam Negeri Alauddin Makassar
}

\begin{abstract}
:
This research is aimed to find outp the frequency of watching on imaginative cartoon channel toward communication pattern at the pre-school children (3-6year-old) in TK Rianti BTN Tamarunang, Kabupaten Gowa. To identify the differences between the communication pattern of the boys and the daughters in TK Rianti BTN Tamarunang, Kabupaten Gowa. The type of this research is correlational aassociative research by quantitative approach. The data are collected from pupils in Taman Kanak-Kanak Riyanti BTN Tamarunang, Kabupaten Gowa. The collecting data is through observation and questionnaire. The sampling technique is through total sampling. The data analysis is executed by SPSS verse 23.0. The result of this research indicates that based on chis-square test can be known df 4 with the point of chi-square 9.49 table. It is due to chisquare about $2.739<$ chis quare table about 9.49 , then $\mathrm{HO}$ is rejected, and $\mathrm{Hi}$ is accepted which means that there is a significant relation and relation of imaginative cartoon channe who like giving a help in Taman Kanak-Kanak Riyanti BTN Tamarunang, Kabupaten Gowa. According to the research points out that the attitude of the boys who are on the high level is about ten boys, though the numbers of daughters are bigger than boys. However, it clarifies that the communicaton pattern of the boys are on the higher than the daughters which strongly indicates there is different attitude between the boys and the daugthers.
\end{abstract}

\section{Key words:}

\section{Imaginative Cartoon Channel, Communication Pattern, Pre-School Pupils}

\section{PENDAHULUAN}

Di era berkembang seperti sekarang ini, televisi merupakan bagian yang tidakterpisahkandalamkehidupan.Tayangan-tayanganyang disajikandi dalamnya merupakan sekumpulan tayangan yang menarik bagi kita. Tidak hanya orang dewasa dan remaja, anakanak pun demikian betahnya untuk berlama-lama duduk didepan layar kacayang banyak menyajikan tayangan- tayangan imajinasi atau sering di sebut film kartun yang disukainya dan dianggap menarik itu.

Minat tersebut akan menimbulkan dampak bagi pola komunikasi pada anak, baik dampak yang positif maupun negatif. Karena tayangan-tayangan imajinasi ini kebanyakan 
memperlihatkan unsur-unsur positif dan negatif pula seperti kehangatan, kasih sayang, persahabatan, kebohongan, kekerasan dan lain-lain. Unsur kekerasan di sini diartikan sebagai setiap tampilan, baik komunikasi verbal (dengan kata-kata) maupun komunikasi non verbal (dengan gambar), yang merujuk pada tingkah laku yang bertujuan untuk melukai, mencelakakan, dan membunuh orang lain atau objek lain yang tidak menginginkan datangnyatingkah laku tersebut (Musbikin, 2009: 21).

Berkembangnya TV yang ada di Indonesia tidak hanya dilihat dari jumlah televisi yang ada, tetapi juga perkembangan itu terlihat dengan berbagai macam acara yang lebih mengutamakan hiburan dari program siaran yang diproduksinya. Salah satu yang banyak menjadi pilihan stasiun televisi untuk ditayangkan adalah film kartun atau animasi yang menarik perhatianaudiens, khususnya anak-anak.Diantaranya Doraemon dan Shinchan di RCTI,Spongebob dan Naruto di GlobalTV, Boboboy dan Upin\&Ipin di MNCTV, Masha and the Bear diANTV dan lain-lain. Hal itu dilakukan karena televisi memiliki kemampuan untuk mempengaruhi khalayak. Kondisi ini menantang para orang tua untuk lebih selektif dan berkompromi dengan anak-anaknya untuk menyaksikan tayangan yang patut dinikmati dan acara yang seharusnya tidak dilihat oleh anak. Apalagi usia anak-anak merupakan usiayang strategis dan lebih mudah terkena pengaruh, baik dari lingkungan dengan kontak langsung maupun media elektronik.

Televisi boleh dikatakan telah mendominasi hampir semua waktu luang setiap orang. Dari hasil penelitian yang pernah dilakukan pada masyarakat Amerika, ditemukan bahwa hampir setiap orang dibenua itu menghabiskan waktunya antara 6-7 jam perminggu untuk menonton TV. Waktu yang paling tinggi terserap pada musim dingin. Australia anak-anak rata terlambat bangun pagi kesekolah karena banyak menonton Tv di malam hari. Sementara itu, di Indonesia pemakaian TV dikalangan anak-anak meningkat pada waktu libur, bahkan melebihi 8 jam perhari (Cangara,2012:156).Karenaitulahtelevisi sangatbesar pengaruhnya dalam mengubah pola komunikasi penontonnya. Imitasi adalah tingka tpertama pengaruh yang kelihatan jelas, dimana anak melihat secara berulangulang perilaku tokoh idolanya dan cenderung meniru perilaku tersebut. Ini bisa dimaklumi karena salah satu perkembangan perilaku seseorang dihasilkan dari contoh mereka yang lebih dewasa, orangtua, keluarga, guru, bahkan orang lain yang menjadi idola.

Film kartun yang bertemakan kepahlawanan misalnya, pemecahan masalah tokohnya cenderung dilakukan dengan cepat dan mudah melalui tindakan kekerasan. Cara-cara seperti ini relatif sama dilakukan oleh musuhnya (tokoh antagonis).Ini berarti tersirat pesan bahwa kekerasan harus dibalas dengan kekerasan, begitu pula kelicikan dan kejahatan lainnya perlu dilawan melalui cara-cara yang sama. Handayani(2006) melakukan penelitian terhadap beberapa film kartun, seperti Naruto, Spongebob, Avatar, Pokemon. Hasil penelitian tersebut menemukan bahwa film-film kartun banyak mengandung adegan antisosial atau kekerasan $68,4 \%$ dari pada adegan prososial31,6\%. Hal ini sangat bertentangan dengan tema utama dari film kartun tersebut yaitu kepahlawanan. Studi ini mengungkapkan bahwa kategori perlakuan anti sosial yang paling seringmuncul berturut-turut adalah berkata kasar 22,56\%, mencelakakan $30,46 \%$ dan pengeekan $15,43 \%$. Kategori prososial, perilaku yang kerap kali 
muncul adalah kehangatan 9,16\%, kesopanan 7,05\%, empati $8,33 \%$, dan nasihat 7,06\% (Handayani, 2006).

Contoh perilaku anak setelah menonton televisi sebagai berikut, bocah 4 tahun bernama Farhat menuju ke balkon karena terbayang akan menjadi monster hebat seperti Pikhacu yang bisa melayang. Begitu sampai di balkon, tanpa basa-basi bocah lelaki itu melompat. Hasilnya bukan monster yang hebat, tapi Farhat masuk rumah sakit. Kakinya patah dan beberapa bagian tubuhnya cukup parah. Contoh tersebut memperlihatkan, betapa besar pengaruh televisi terhadap perilaku anak. Dari fenomena yang ada maka dapat diketahui bagaimana seorang anak dapat menirukan adegan yang ada di dalam tayangan televise baik itu secara verbal maupun non verbal (tingkah laku) tanpa mereka sadari dan saat mereka melihat tayangan ditelevisi tanpa ada pengawasan dari orang tua mereka (Amini, 2008: 4).

Pernyataan tersebut menunjukkan bahwa tayangan imajinatif di sini merupakan suatu stimulus penyampaian pesan yang kemudian diserap oleh anak-anak dan anak-anak akan memberikan feedback dari stimulus atau tayangan imajinatif tersebut maka berpengaruh terhadap pola komunikasi anak. Artinya, ketika mereka banyak menonton tayangan ini maka mereka banyak pula belajar dan menyerap serta menirunya. Tak heran, jika banyak anakyang suka berbohong, mengeluarkan kata-kata yang kurang ajar kepada kedua orang tuanya maupun orang lain dan suka membuatorang marahdan jengkel. Belum lagi hasil penelitian yang menunjukkan perilaku kasar dan agresif pada anak, yang setelah diteliti lebih lanjut ternyata merupakan dampak dari menonton tayangan tersebut. Dengan kata lain tayangan ini akan sangat berdampak pada pola komunikasi anak .

\section{TINJAUAN TEORITIS}

\section{Khalayak dalam Komunikasi Massa}

Khalayak media berlaku universal dan secara sederhana diartikan sekumpulan orang yang menjadi pembaca, pendengar, pemirsa berbagai media. Kumpulan ini disebut sebagai khalayak dalam bentukyangpaling dikenalidan versi yang diterapkandalam hampir seluruh penelitian media itu sendiri. Menurut Wright, dalam komunikasi massa khalayak relative besar, heterogen, anonim bersumber. Dalam komunikasi massa tidak memungkinkan komunikator untuk bertatap muka dengan anggota-anggota khalayaknya. Selain merupakan kelompok yang beranekaragam, kebanyakan penerima pesan juga tidak dikenal oleh sumber pesan (Tubbs\&Moss, 200: 198-200).

Berkaitan dengan komunikan yang beranekaragam tersebut, pesan (message) komunikasi massa bersifat public atau tidak diajukan kepada perseorangan. Pesan tersebut juga mewakili usaha banyak orang yang berlainan, yaitu orang-orang terlibat sebagai komunikator. Pesannya bersifat umum, disampaikan secara cepat dan serentak. Meskipun ada kalanya khalayak juga menyampaikan pesan, namun komunikasi massa di dominasi olehkomunikator karena pada akhirnya komunikatorlah yang menentukan agendanya (Mulyana,2007:83-84). Komunikasi mempunyai sedikit atau bahkan tidak memiliki sama sekali control atas sumber-sumbernya sehingga umpan balik (feedback) juga tidak segera. 
Dalam beberapa kasus, pembaca surat kabar, dan televisi bisa saja menyampaikan umpan balik secara langsung. Namun tetap saja umpan balik tersebut tidak lengkap, karena umpan balik non verbal, seperti ekspresi wajah dan tubuh dari pemberi umpan balik sering tidak tertangkap oleh sumber pesan.

Teori uses and gratification, teori ini memprediksi bahwa khalayak tergantung pada informasi yang berasal dari media massa dalam rangka memenuhi kebutuhan khalayak bersangkutan serta mencapai tujun tertentu dari proses konsumsi media massa, namun perlu di garis bawahi bahwa khalayak tidak memiliki ketergantungan yang sama terhadap semua media. Misalnya, terdapat audiens yang benar-benar menerima hal-hal yang ditawarkan dan diterima.

Perkembangan teknologi komunikasi massa dalam bentuk media massa khususnya media televise telah membuat dunia semakin kecil. Tren perubahangaya hidup masyarakat tidak hanya membawa pengaruh globalisasi melainkan juga polaris baruyang mendorong dilakukannya dalam berbagai bidang kehidupan (Kuswandi,W.2008:33). Oleh karena itu, kita dituntut untuk siap menghadapi banjirnya informasi melalui medium televise yang mengalir melintasi batas-batas Negara hingga tidak dapat tebendung oleh jarak dan waktu.

Ciri lain yang dimiliki komunikasi massa ialah sumber dan penerima di hubungkan oleh saluran yang telah diproses secara mekanik. Proses penyampaian pesannya lebih formal, terencana (dipersiapkan lebih awal), terkendali oleh redaktur dan lebih rumit, dengan kata lain melembaga (Cangara, 2011: 37).

Komunikasi massa adalah komunikasi melalui media massa (media cetak dan elektronik). Komunikasi massa lebih menunjuk pada penerima pesan yang berkaitan dengan media massa. Dengan kata lain, massa yang dalam sikap dan perilakunya berkaitan dengan peran media massa. Oleh karena itu, massa disini menunjuk kepada khalayak, audience, penonton, pemirsa, atau pembaca (Nurudin,2004:2). Dan yang menjadi media antaralain: televisi, radio, internet, majalah, koran, tabloid, buku, dan film.

Komunikasi massa memiliki 5fungsi. 1) fungsi pengawasan, fungsi pengawasan yaitu media masssa sebagai medium untuk melakukan control sosial dan kegiatan persuasif. 2) fungsi social learning, yaitu media massa berperan melakukan pendidikan bagi masyarakat. 3) fungsi penyampaian informasi, yaitu komunikasi massa melalui media massa memungkinkan informasi tersampaikan secaraluas dan cepat.4) fungsi transformasi budaya lebih kepada tugas media massa yang besar sebagai bagian dari budaya global. 5) fungsi hiburan.(Bungin,2009: 78-81)

Fungsi hiburan merupakan penyebarluasan sinyal, symbol, suara, dan citra (image) dari kesenian, kesustraan, musik, olahraga dan sebagainya untuk rekreasi dan kesenangan kelompok individu. Karena didalamnya terdapat kegiatan suatu organisasi yang memproduksi serangkaian pesan dengan bantuan mesin untuk disebarkan. Misalnya, TV menayangkan hiburan tayangan imajinatif kartun yang lebih mengarah keminat anak-anak. Televisi adalah siaran untuk umumyang menyiarkan programnya secara universal, tetapi fungsi utamanya 
adalah tetap hiburan, meskipun ada program-program yang mengandung segi informasi dan pendidikan, program tersebut hanya sebagai pelengkap saja dalam rangka memenuhi kebutuhan alamiyah manusia.

Television atau televise merupakan media komunikasi jarak jauh dengan penayangan gambar pendengaran suara, baik melalui kawat maupun secara elektromagnetic tanpa kawat.(Effendy,1989:361).Adapun fungsi siaran televisi menurut Bambang (Bambang, 2000: 83)

1. Fungsi penerangan, fungsi ini didukung olehsifat-sifat yang dimiliki televisi, yakni.

a. Sifat immediacy. Suatu peristiwa yang disiarkan dapat dilihat dan didengar pada saat peristiwa itu berlangsung. Seakan-akan berhadapan dengan peristiwa itu, atau dengan kata lain bersifat tidak media.

b. Sifat realisme, artinya berdasarkan kenyataan atau sekan-akan nyata.Sifat inilah lebih mengefektifkan fungsi peneranganbagi polakomunikasi anak.

2. Fungsi hiburan. Fungsi ini menempati porsi yang lebih banyak dibandingkan dengan fungsi lainnya. Hampir semua sajian televisi berbobot hiburan, beritapun tidak lepas dari berita yang menggelitik. Fungsi hiburan,lebih dominan pada penelitian ini, karena tayangan imajinatif termasuk hiburan bagi anak-anak.

3. Fungsi pendidikan. Fungsi televise dalam pendidikan bersifat massal, tidak dibatasi oleh ruang kelas.

Tayangan televise berpengaruh negative terhadap perkembangan perilaku anak tergantung dari penyesuaiannya "Anak yang penyesuaiannya baik kurang kemungkinannya terpengaruh secara negatif, apakah permanen atau temporer dibandingkan dengan anakyang buruk penyesuaiannya, dan anak yang sehat dibanding anak yang tidaksehat."Anak-anak melakukan sesuatu sesuai apa yang mereka lihat dan dengarkan, bukan apa yang baik untuk mereka, karena anak-anak masih belum mampu membedakan mana yang baik, dan mana yang buruk (Hurlock, 1978:344).Oleh karena itu, orang tua harus dapat membatasi apayang dilihat dan didengar melalui televisi.Televisi dengan berbagai acara yang ditayangkannya telah mampu menarik minat pemirsanya dan membuat pemirsanya ketagihan untuk selalu menyaksikan acara-acara yang ditayangkan bahkan, termasuk anak-anak sekalipun.

Televisi sudah menjadi bagian yang tidak terpisahkan dari aktivitas kesehariannya sebagai agenda wajib. Tayangan imajinatif kartun membuat banyak anak-anak yang lebih suka berlama-lama di depan televise dari pada membaca yang justru dapat meningkatkan daya imajinasi mereka. Bahkan banyak anak yang lupa untuk makan karena televisi. Hal ini merupakan suatu masalah yang terjadi saat ini, karena seharusnya anak lebih banyak mencari informasi melalui buku daripada televisi. Setiap orang tua perlu memperhatikan secara khusus tayangan bagi anaknya, karena tayangan dalam televisi tidak terlepas dari adegan-adegan kekerasan yang dapat dengan mudah ditiru oleh anak. 
Berikut teori-teoriyang menjelaskan komunikasi massa:

\section{Teori Peluru (hypodermic)}

Gagasan bahwa komuni kasimassa memiliki kekuatan besar dapa tdianggap sebagai salah satu teori umum pertama tentang komunikasi massa. Kadang teori ini dikenal dengan teori peluru (Schramm, 1971), teori jarum suntik (Berlo, 1960), atau teori stimulus respons. Teori ini mengatakan bahwa rakyat benar-benar rentan terhadap pesan-pesan komunikasi massa .Ia melibatkan bahwa apabila pesan "tepat sasaran", ia akan mendapatkan efek yang diinginkan. (Severin,W.Jdan Tankard Jr, James, 2008: 146).

Hypodermic theory mengasumsikan media massa mempunyai pemikiran bahwa audience bisa ditundukkan sedemikian rupa atau bahkan bisa dibentuk dengan cara apapun yang dikehendaki media. Intinya sebagaimana dikatakan Jason dan Anne Hill (1997), media massa dalam teori jarum hipodermik mempunyai efek langsung "disuntikkan" kedalam ketidaksadaran khalayak (Nurudin, 2007:166).

Berdasarkan teori ini, media massa seperti peluru yang ditembakkan ke tengah masyarakat. Media massa dipandang sebagai jarum suntik untuk mengalirkan obat kedalam tubuh manusia. Media berperan secara otomatis untuk memasukkan pesan-pesan kepribadipribadi dan masyarakat umum. Isi media dipandang sebagai obat yang disuntikkan kedalam pembuluh darah audience yang kemudian diasumsikan akan bereaksi seperti yang diharapkan.

\section{Teori Kultivasi (cultivation theory)}

Kultivasi berasaldari kata Cultuvation (Inggris),yang berarti penguatan, pengembangan, penanaman atau pemerataan. Teori ini digagas pertama kali oleh George Gerbner pada 1968 Kriyantono,2012: 285). Kultivasi adalah salah satu riset yang digunakan untuk melihat seberapa besar efek social terpaan media massa, selain agenda setting dan uses and gratification. Kultivasi merupakan efek media massa, jangka panjang, khususnya pemirsa televisi (McQuail, 2001: 256).

Teorikultivasi dalam bentuk yang paling dasar menunjukkan paparan bahwa sesungguhnya televise dari waktu kewaktu secara halus menumpuk persepsi pemirsa tentang kehidupan realitas. Teori ini dapat memiliki dampak pada pemirsaTV,dan dampak tersebut akan berdampak pula pada seluruh budaya khalayak.

Teori kultuvasi adalah teori yang mengatakan bahwa menonton televisi secara barangsur-angsur mengarahkan pada adopsi keyakinan mengenai sifat dasar dari dunia social yang mengikuti pandangan akan realitas yang memiliki stereotip, terdistorsi dan sangat selektif sebagaimana yang digambarkan dengan rencana yang sistematis difiksi dan berita televisi (McQuail, 2001: 257).

\section{Tayangan Imajinatif Kartun}

Tayangan dapat diartikan suatu proses produksi yang dilakukan oleh stasiun televise untuk menyampaikan informasi ataupun entertainment yang terprogram melalui media audio- 
visual sebagai reproduksi dan kenyataan yang dipancarkan dengan gelombang elektronik sehingga dapat disaksikan khlayak umum melalui layar televisi.

Tayangan imajinatif kartun adalah ide atau gambaran sesuatu berupa animasi yang ditayangkan. Dibawah ini beberapa contoh tayangan imajinatif diantaranyaadalah:

a. Crayonshinchan, dalam versikomik volume 1, digambarkan orang tua Shinchan sedang (maaf) menyalurkan hubungan biologis tanpa mengunci pintukamar.

b. Sponge Bobs, film kartun yang sedang marak dibicarakan ini mengajarkan anak untuk bertindak ceroboh,dan berfikir menyimpang. Walau terkesan lucu dan konyol, namun hal tersebut dapat berakibat buruk bagi anak-anak.

c. Tom and Jerry,dalam film ini, Tom dan Jerry selalu bermusuhan, dan tidak jarang mengandung kekerasan di dalamnya. Contohnya adalah ketika Jerry sedang dikejar- kejar oleh Tom, tiba-tiba Jerry menemukan pisau dan langsung menusukkaan pisau tersebut kepada Tom. Selain terdapa tkekerasan, film ini mengajari anak-anak untuk selalu bermusuhan terhadap temannya, seperti Tom dan Jerry yang tidak pernah akur.

d. Doraemon, film kartun ini juga dianggap berbahaya bagi anak-anak karena terdapat halhal yang sangat tidak masuk akal di dalamnya. Dalam berbagai episodenya, banyak dikisahkan bagaimana Doraemon menemukan berbagai kekuatan ajaib dari kantungnya untuk memecahkan masalah yang dihadapi Nobita. Kekuatan ajaib itu bisa diidentikkan dengan imajinas ianak-anak untuk mendapatkan sesuatu dengan mudah.

\section{Orientasi Pola Komunikasi Anak Usia Pra-Sekolah}

Pola komunikasi diartikan sebagai bentuk atau pola hubungan dua orang atau lebih dalam proses pengiriman dan penerimaan carayang tepat sehingga pesan yangdimaksud dapat dipahami (Djamarah, 2004:1).

Dimensi pola komunikasi terdiri dari dua macam, yaitu pola yang beriorentasi pada konsep dan pola yang beriorentasi pada social yang mempunyai arah hubungan yang berlainan. Disini kita mulai melihat bagaimana proses interaksi menciptakan struktur sistem. Bagaimana anak usia prasekolah merespon media dengan menentukan jenis hubungan yang mereka miliki. Salah satu cara yang umum dalam menjelajah lingkungan adalah dengan bertanya "mengapa" dan untuk "apa", karena anak seusia ini dipenuhi dengan keingintahuan. Anak usia prasekolah adalah seseorang yang berusia 3-6 tahun yang sedang dalam masa tumbuh kembang dengan kebutuhan khusus baik kebutuhan fisik, psykologis, social, dan spiritual yang berbeda dengan orang dewasa (Supartini,2004: 45).

Usia pra sekolah sering disebut juga masa kanak-kanak atau usia kelompok, masa anakanak mempelajari dasar-dasar perilaku social sebagai persiapan bagi kehidupan sosialyang lebih tinggi yang diperlukan untuk penyesuaian diri pada waktu mereka masuk kelas satu. Karena perkembangan utama yang terjadi selama awal masa kanak-kanak berkisar pada penguasaan dan pengendalian lingkungan, banyak ahlip sikologi yang melabelkan masa 
kanak-kanak sebagai usia menjelajah, sebuah label yang menunjukkan anak ingin mengetahui keadaan lingkungannya dan bagaimana ia dapat menjadi bagian dari lingkungannya.

\section{METODE PENELITIAN}

\section{Jenis Penelitian}

Penelitian ini menggunakan pendekatan deskriptif kuantitatif dengan maksud untuk mengetahui hubungan frekuensi menonton tayangan imajinatif dengan pola komunikasi anak. Jenis penelitian yang digunakan adalah korelasional yang bersifata sosiatif yaitu menjelaskan hubungan antara variable $\mathrm{X}$ dan $\mathrm{Y}$ yang akan diteliti dengan cara mengumpulkan data melalui instrumen penelitian, dan menyebarkan kuesioner kepada ibu atau orang tua yang bersedia untuk menjadi responden yang hasilnya kemudian diolah melalui program SPSS untuk mengetahui hubungan antar variabel yang ada.

\section{Variabel PenelitiandanOperasionalisasi}

\section{Variable penelitian}

Variabel $\mathrm{x}$ dalam penelitian ini adalah sebagai frekuensi menonton tayangan imajinatif, sedangkan variable y adalah pola komunikasi anak usia prasekolah.

\section{Operasionalisasi}

Operasionalisasi adalah serangkaian langkah-langkah prosedur dan sistematis yang menggambarkan kegiatan untuk mengukur dan mendapatkan ekstensi empiris dari suatu konsep. Operasionalisasi tergambar dalam tabel berikutini:

\section{Tabel 1.1Operasionalisasi}

\begin{tabular}{|c|c|c|c|c|c|}
\hline \multirow{2}{*}{ Variabel } & \multirow{2}{*}{ Konseptualisasi } & \multirow{2}{*}{ Operasional } & \multirow{2}{*}{ Indikator } & \multicolumn{2}{|c|}{ Alat ukur } \\
\hline & & & & Data & Skala \\
\hline $\begin{array}{l}\text { Pengaruh } \\
\text { tayangan } \\
\text { imajinati } \\
\text { f }\end{array}$ & $\begin{array}{l}\text { Frekuensi } \\
\text { menonton }\end{array}$ & $\begin{array}{l}\text { Jumlah waktu yang } \\
\text { digunakan dalam } \\
\text { menonton tayangan } \\
\text { imajinatif kartun }\end{array}$ & $\begin{array}{l}\text { Jam } \\
\text { Dalam } \\
\text { semingg } \\
\mathrm{u}\end{array}$ & Oridinal & Likert \\
\hline $\begin{array}{l}\text { Pola } \\
\text { komunikasi } \\
\text { anak } \\
\text { prasekolah }\end{array}$ & Perilaku anak & $\begin{array}{l}\text { Berkata kasar, } \\
\text { bertengkar dengan } \\
\text { temannya, merengek } \\
\text { jika menginginkan } \\
\text { sesuatu, malas belajar, } \\
\text { suka berbohong }\end{array}$ & Tindakan & Oridinal & Likert \\
\hline
\end{tabular}

\section{Populasidan Sampel}

Populasia dalah wilayah generalisasi yang terdiri atas: obyek/subyek yang mempunyai kualitas dan karakteristik tertentu yang ditetapkan oleh peneliti untuk dipelajari dan kemudian ditarik kesimpulannya (Sugiyono, 2013:80). Populasi pada penelitian ini adalah semua anak usia prasekolah di TK Rianti BTN Tamarunang 
Kabupaten Gowa yang berjumlah 31 anak. Karena pendekatan populasi terbilang kecil maka peneliti menggunakan total sampling.

\section{Teknik Pengumpulan Data}

Dalam penelitian ini, penulis akan menggunakan pengumpulan datayaitu:

a. Data sekunder merupakan data yang diperoleh melalui sumber yang telah ada dengan menumpulkan data yang diperoleh melalui studi kepustakaan.

b. Data primer merupakan data yang langsung diperoleh dari sumber data pertama di lokasi melalui sebagai berikut:

1) Kuesioner

2) Metode Observasi

\section{Teknik Analisis Data}

Setelah memperoleh nilai-nilai dari tiap tabel, selanjutnya data dianalisa dengan menggunakan komputer program SPSS. Analisa data yang digunakan yaitu:

1) Analisa Univariat

Analisa ini dilakukan untuk tiap-tiap variable yang diteliti dari hasil penelitian, yang kemudian akan mendapatkan hasil dari hubungan tayangan imajinatif terhadap pembentukan perilaku padaanak usia prasekolah.

2) Analisa Bivariat

Analisa bivariat dilakukan untuk melihat hubungan variabel independen dengan dependen dalam bentuk tabulasi silang antara kedua variable tersebut. Menggunakan uji statistic dengan tingkat kemaknaan yang dipakai adalah $\alpha=0,05$ dengan menggunakan rumuschi-square

$(\mathrm{Oi}-\mathrm{Ei})^{2}$

$\mathrm{X}^{2}=\sum_{-}$

$\mathrm{Ei}$

Keterangan:

$\mathrm{X}^{2}$ : Nilai chi-squaretest

0 : Nilai observasi

E : Nilaiyangdiharapkan

$\sum \quad$ : Jumlah data

\section{Penilaian:}

1. Apabila nilai $X^{2}$ hitung $>$ dari $X^{2}$ tabel, $\mathrm{H}_{0}$ diterima atau $\mathrm{Ha}_{\mathrm{a}}$ ditolak, artinya tidak ada hubungan antara variable indepen den dengan variabel dependen.

2. Apabila nilai $X^{2}$ hitung $\leq$ dari $X^{2}$ tabel, $H_{0}$ diterima atau $\mathrm{Ha}_{a}$ ditolak, artinya tidak ada hubungan antara variable independen dengan variabel dependen. 


\section{HASILDANPEMBAHASAN}

Frekuensi menonton tayangan kartun imajinatif dengan pola komunikasi anak prasekolah menunjukkan bahwa yang sering di tonton atau disaksikan oleh anak lebih dari 2 jam dalam seminggu. Pola komunikasi yang dimaksud dalam penelitian inia dalah perilaku anak prasekolah dalam aktifitas sehari-hari ditandai dengan berkelahi, perkataankasar, merengek, suka berbohong, malas belajar, suka menolong, tidak membantah, sertapandai berbahasa asing.

Berdasarkan hasil penelitian di atas sesuai hasil yang tertera pada penelitian tersebut orang tua memiliki kekuatan yang cukup besar dalampembentukanperilaku anak. Jika anak sering menonton tayangan imajinatif maka orang tua ikut memberikan bimbingan kepada anak tentang apa yang ditontonnya, hal tersebut yang menjadi tanggung jawab orang tua untuk menciptakan lingkungan yangkondusif maka akan berpotensia dan punya konstribusi positif kepada anak. Peran orang tua sangat menentukan baik-buruk serta utuh-tidaknya kepribadian anak. Untuk itu orang tua pasti akan dimintai pertanggungjawaban dihadapan Allah Azza wa Jalla kelak diakhirat tentang anak-anaknya. Rasulullah Shallallahu 'alaihi wasallam bersabda:

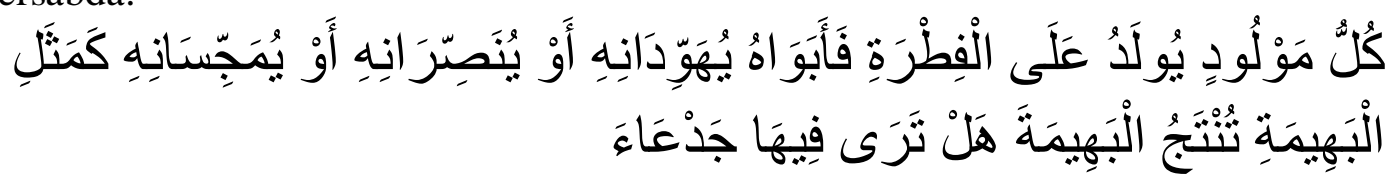

Artinya; :

Tiada seorangpun yang dilahirkan kecuali dilahirkan pada fithrah (Islam)nya. Kedua orang tuanyalah yang menjadikannya Yahudi, Nasrani atau Majusi.[HR. al-Bukhâri dan Muslim]

Hadits ini menunjukkan bahwa orang tua sangat menentukan shaleh- tidaknya anak. Sebab pada asalnya setiap anak berada pada fitrah Islam dan imannya; sampai kemudian datanglah pengaruh-pengaruh luar, termasuk benar-tidaknya orang tua mengelola mereka. Banyak orang yang tidak memperhatikan pertumbuhan anak. Tontonan yang tidak mendidik dan pendidikan yang tidak berkualitas harus dijalani oleh anak usia prasekolah tersebut. Penelitian ini memang sangat berkaitan dengan kualitas agent of change dimasa yang akan datang. Apalagi usia anak prasekolah merupakan usiayang strategis dan lebih mudah terkena pengaruh, baik dari lingkungan dengan kontak langsung maupun media elektronik. Orang tua lebih tahu memilih tontonan yang layak untuk anak-anak sesuai dengan adab islam dalam menerima kabar sesuai firmanAllah surah al-hujurat ayat 6 :

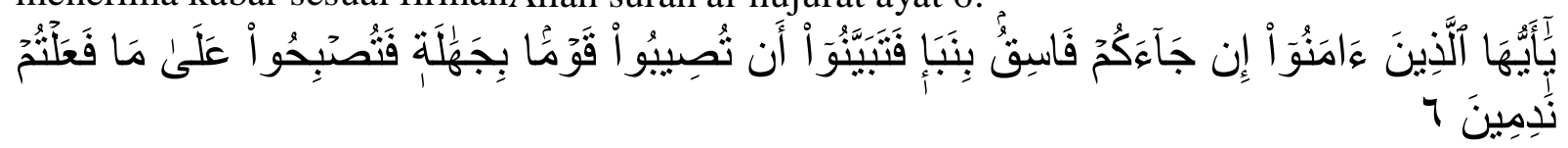

Terjemahnya:

Haiorang-orangyang beriman,jika datang kepadamu orang fasik membawa suatu berita,maka periksalah dengan teliti agar kamu tidak menimpakan suatu musibah 
kepada suatu kaum tanpa mengetahui keadaannya yang menyebabkan kamu menyesal atas perbuatanmu itu."(QS.Al Hujurat :6)

Ayat ini memberikan penjelasan bagi umat manusia semuanya untuk selalu tabayun dalam segala berita yang disampaikan oleh orang muslim maupun non muslim. Kemudian ayat ini menyuruh kita berhati-hati dalam menindakkan sesuatu yang akibatnya tidak dapat diperbaiki (perkataannya banyak menimbulkan kerusakan), supaya tidak ada pihak atau kaum yang dirugikan, dtimpa musibah atau bencana ysng disebabkan berita yang belum pasti kebenarannya, sehingga menyebabkan penyesalan yang terjadi (IbnuKatsir, Tafsir Ibnu Katsir 7:316). Ayat ini menolak berita orang-orang fasiq dan mensyaratkan keadilan, baik dia perawi ataupun saksi, dan membolehkan kita menerima khabar seorang yang adil (Tafsir Bayaan, 4: 1363). Secara historis, bahwa yang melakukan perbuatan fasiq dalam ayat tersebut adalah orang muslim (M. Quraish Shihab, Tafsir Al Misbah 13: 237), sehingga tidak ada jaminan bahwa jika seseorang telah memeluk agama Islam telah berlaku baik dalam segala aspek. Hal ini lebih dipertegaskan kepada orang tua untuk lebih selektif dan berkompromi dengan anakanaknya untuk menyaksikan tayangan yang patut dinikmati dan acara yangseharusnya tidak dilihat oleh anak.

Media elektronik merupakan suatu alat yang melebihi budaya dalam mempengaruhi daya imajinasi dan perilaku anak. Hal ini terkait dengan cultivation theory yang menunjukkan bahwa tayangan TV yang disampaikan melalui pesan komunikasi yang langsung disuntikkan kepada khalayak dengan maksud untuk mengubah perilaku sesuai yang ditujukan oleh media TV. Sama halnya dengan asumsi teori jarum hipodermik yang dikesankan bahwa pesan komunikator disuntikkan langsung ke dalam jiwa komunikan kemudian mempunyai efek atau pengaruh yang sangat kuat yangsesuai dengan hasil penelitian.

Berdasarkan hasil penelitian yang diperoleh data bahwa dari 31 anak responden, didapatkan hasil penelitian anak yang sering menonton dengan perilaku sering berkelahi dengan temannya pada kategori tinggi, berarti memberikan respon yang signifikan terkait anak yang sering berkelahi. Ahli psikologi, Albert Bandura dari Universitas Standford, mengadakan eksperimen untuk mengetahui seberapa efektifnya anak-anak melakukan peniruan terhadap perilaku agresif. Dalam eksperimen itu, ditemukan bahwa anak-anak belajar mengenal perilaku agresif dengan meniru orangdewasa. Anak-anak tersebut melihat seorang model melakukan kekerasan memukul, menendang dan menduduki boneka badut. Setelah mengamati model, anak-anak tersebut ditaruh diruangan besar bersama boneka badut, secara tidak langsung anak-anak tersebut melakukan tindakan yang sama persis dilakukan oleh model sebelumnya (Bailey,1988:45). Beberapa ahli psikologi berpendapat bahwa kekerasan sama sekali bukanlah hal yang ditetapkan secara genetik, melainkan sepenuhnya merupakan hasil belajar. Manusia belajar lewat peniruan, mengambil pola-pola perilaku yang mereka lihat dari sekitar mereka, dan juga melalui proses umum yang disebut pembiasaan. Baik peniruan maupun pembiasaan dimulai dari rumah, tetapi banyak dipengaruhi oleh dunia luar yang lebih luas, baik oleh sekolah, tradisi nasional dan agama maupun oleh buku, majalah, surat kabar terutama film dan televise (Bailey 1988:44) 
Hasil penelitian menguraikan bahwa anak responden yang sering menonton tayangan imajinatif dengan perilaku berkata kasar dengan teman dan orang tuanya pada kategori tinggi, hal ini mengindikasikan bahwa anak yang sering menonton tayangan imajinatif memberikan respon perilaku yang kurang baik, yakni adanya hubungan yang signifikan. Sebagai contoh kalimat yang sering muncul di tayangan kekerasan asing adalah "Whatthe fuck?". Dalam tayangan kekerasan Indonesia kata yang paling sering diucapkan berhubungan dengan hewan tertentu (anjing, babi, monyet) dengan nada tinggi untuk menekankan emosi pada kata tersebut. Dalam Islam bisa dikatakan bahwa etika bicara itu merupakan menjaga lisan dalam mengkomunikasikan sesuatu, karena setiap kata-kata yang diucapkan kita bisa mendapat pahala apa bila perkataan itu baik dan hendaknya pembicaran selalu di dalam kebaikan. Dalam kaitannya Al-Qur'an surah An-nisa ayat 114, Allah berfirman

\section{Terjemahnya:}

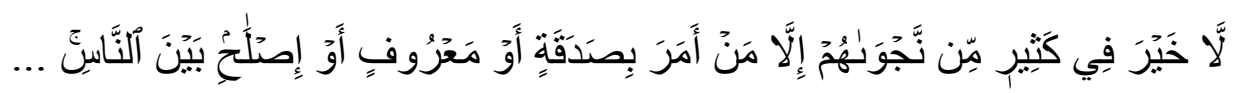

"Tidak ada kebaikan pada kebanyakan bisik-bisikan mereka, kecuali bisik- bisikan dari orang yang menyuruh (manusia) member sedekah atau berbuat ma`ruf, atau mengadakan perdamaian diantara manusia". (An-Nisa: 114).

Syaikh Abdur Rahman bin Nashir As-Sa'di Rahimahulloh berkata“ Maknanya adalah tidak ada kebaikan pada kebanyakan bisikan-bisikan manusia dan perbincangan mereka apabila tidak mengandung kebaikan padanya karena boleh jadi hal tersebut tidak ada manfaatnya seperti memperbanyak perbincangan yang mubah, maupun keburukan atau mudarat yang murni seperti perkataan yang diharamkan dengan berbagai macamnya.

Terjemahan di atas menjelaskan perilaku orang-orang muslim wajib menjaga lisannya, tidak boleh berbicara batil, dusta, menggunjing, mengadu domba dan melontarkan ucapanucapan kotor, ringkasnya, dari apayang diharamkan Allah dan Rasul-Nya. Sebab kata-kata yang merupakan produk lisan memiliki dampak yang luar biasa. Perang, pertikaian antar negara atau perseorangan sering terjadi karena perkataan dan provokasi kata. Sebaliknya, ilmu pengetahuan anak lahir, tumbuh dan berkembang melalui kata-kata.

Anak yangsering menonton tayangan imajinatif memberikan respon yang signifikan pada kategori tinggi yangsering merengek jik amenginginkan sesuatu. Sama halnya yang dikemukakan Michele Borba, Ed. D, dalam bukunya don't give me that Attitude!: 24 selfish, rude behaviors and how to stop them menjelaskan bahwa anak-anak yang selfish alias egois adalah anak-anak yang tidak senang menjadi bagian daris ekitarnya. Mereka selalu menginginkan segala sesuatu sesuai dengan cara mereka, meletakkan kebutuhan dan urusan mereka di atas yang lainnya, dan jarang sekali mempertimbangkan perasaan orang lain. Itulah sebabnya, mereka berusaha membuat orang tuanya percaya bahwa perasaan mereka lebih penting dibandingkan perasaan dan kebutuhan orang lain.

Hasil penelitian menunjukkan bahwa terdapat hubungan yang signifikan anakyang sering menonton tayangan imajinatif memberikan respon malas belajar. Dengan hasil seperti 
ini dapat di pastikan kualiatas manusia Indonesia terbilang semakin menurun. Penyalagunaan teknologi yang menjadikan anak kurang termotifasi untuk belajar, sesuai dalam undang undang dasar1945 alinea ke 4yaitu "mencerdaskan kehidupan bangsa". Dalam Islam pendidikan sangatlah penting. Dalam firman Allah Swt. surah Al-lukman ayat 12

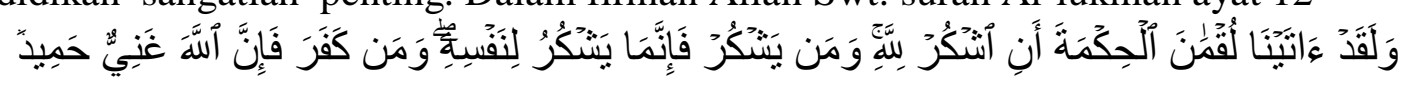

Terjemahnya:

Dan sesungguhnya telah Kami berikan hikmat kepada Luqman, Yaitu: "Bersyukurlah kepada Allah.dan Barang siapa yang bersyukur (kepadaAllah), maka mesungguhnya ia bersyukur untuk dirinya sendiri; dan barang siapayang tidak bersyukur, maka sesungguhnya Allah Maha Kaya lagi Maha Terpuji”. (QS.Luqman: 12)

Hasil penelitian berikutnya yang menunjukkan adanya hubungan yang signifikan antara anak yang sering menonton tayangan imajinatif dengan perilaku mengejek temannya. Sama dengan asumsi Gentile and Bushman seorang pakar psikologi anak, ada enam factor yang dapat menyebabkan anak menjadi pengganggu ata umelakukan bullying terhadap temannya. Ketika semua faktor-faktor risiko yang dialami oleh anak-anak, maka serangan dan perilaku intimidasi akan semakin tinggi.1-2 faktor risiko bukanlah masalah besar bagi anakanak, peran penting dan perhatian orang tua akan membantu untuk mengatasi tindakan bullying" kata Gentile.

Berdasarkan hasil penelitian, bahwa anak yang sering menonton tayangan imajinatif menunujukkan perilaku suka menolong berada pada kategori rendah. Dalam hal ini dorongan untuk menolong akan muncul jika anak memiliki kepekaan. Namun kepekaan tanpa dasar ilmu yang jelas, tidak membantu anak untuk mengerti apa yang harus diperbuat. Tidak pula mengerti apakah yang dilakukan berada dalam koridor kebenaran menurut agama atau tidak. Sementara benar tidaknya perbuatan kita, meskipun dilakukan dengan niat baik, sangat menentukan nilai perbuatan tersebut dihadapan Allah Swt. Dalam ajaran Islam sifat ta'awun ini sangat diperhatikan, hanya dalam kebaikan dan takwa, dan tidak ada tolong-menolong dalam hal dosa dan permusuhan. Oleh karena itu sifat ta'awun atau tolong-menolong termasuk akhlak terpuji dalam agama Islam. Dalil Al qur'an dalam Firman Allah dalam surah maidah ayat 2

Terjemahnya;

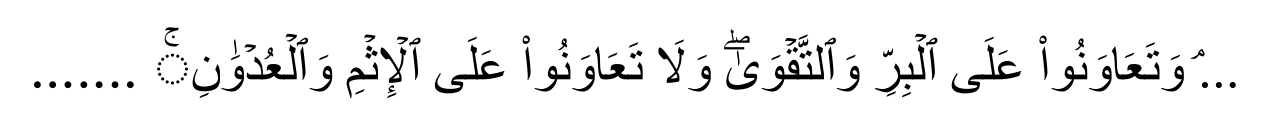

Dan tolong-menolonglah kamu dalam (mengerjakan) kebajikan dan takwa, dan jangan tolong-menolong dalam berbuat dosa dan permusuhan".

Ayat tersebut mengajarkan hendaknya membiasakan diri untuk bersikap ta'awun atau saling menolong mulai dari hal-hal yang kecil. Misalnya meminjamkan pensil atau penghapus kepada teman yang memerlukan, menunjukkan alamat kepada orang yang menanyakan alamat kepadamu, menyampaikan kabar tentang temanmu yang tidak masuk sekolah karena sakit, dan sebagainya.

Anak yang sering menonton tayangan imajinatif tidak mendapatkan responpositif pada indicator penelitian (pandai berbahasa asing) yang berada pada kategori rendah. Hal ini 
mengasumsikan bahwa anak tidak mudah paham berbahasa asing hanya dengan menonton tayangan kartun, melainkan menggunakan metode seperti yang dikemukakan James Asher, seorang professor psikologi Universitas Negeri San Jose California, adalah metode yang sesuai untuk mengajarkan bahasa Inggris pada anak usia dini dimana pembelajarannya lebih mengutamakan kegiatan langsung berhubungan dengan kegiatan fisik (physical) dan gerakan (movement). Dalam metode TPR ini, Asher mengatakan bahwa semakin sering atau semakin intensif memori seseorang diberikan stimulasi maka semakin kuat asosiasi memori berhubungan dan semakin mudah untuk mengingat (recalling). Kegiatan mengingat ini dilakukan secara verbal dengan aktifitas gerak (motor activity).

Berdasarkan uji chis-quare dapat diketahui bahwa dengan df 4 dengan nilai Chisquare table 9,49. Karena nilai chisquare hitung $=2.739<$ chi square tabel $=9,49$. Dengan demikian $\mathrm{H} 0$ ditolak dan $\mathrm{Hi}$ diterima yang berarti ada hubungan yang signifikan, dan terdapat hubungan tayangan imajinatif anak yang suka menolong di Taman Kanak-kanak Riyanti BTN tamarunang Kabupaten Gowa

Hasil penelitian ini sama dengan teori Albert Bandura dan Richard Walters dalam Syailendra Putra (2009:45) bahwa kita belajar banyak perilaku melalui peniruan bahkan tanpa ada penguat sekalipun yang kita terima. Selanjutnya teori yang dikemukakan oleh Bandura dan Warters bahwa ternyata anak-anak bisa berperilaku agresif hanya dengan mengamati perilaku agresif dari sosok model yang diamati, misalnya film kartun.

Hasil penelitian menunjukkan bahwa tayangan imajinatif sangat memengaruhi pola komunikasi anak usia prasekolah. Seperti percobaan Bobo Doll yangdilakukan oleh Albert Bandura. Dimana ada dua orang anak yang ditemani mainan boneka Bobo ditempatkan diruangan yang berbeda dan mendapatkan tayangan yang bebeda. Satu ditunjukkan tayangan kasih dan yang lain ditunjukkan tayangan aksi. Hasilnya, anak yang ditunjukkan tayangan kasih sayang, mainan dan bonekanya utuh. Berbeda dengan anak yang ditunjukkan tayangan aksi. Mainan dan bonekanya rusak karena anak tersebut menirukan apa yang ada di tayangan yang ditonton.

\section{SIMPULAN}

1. Berdasarkan hasil penelitian yang telah dilakukan Taman Kanak kanak Riyanti BTN Tamarunang kabupaten Gowa dapat disimpulkan bahwa terdapat hubungan yang signifikan tayangan imajinatif dengan pola komunikasi. Dari uji chis-quare dapat diketahui bahwa dengan df 4 dengan nilai Chisquare table 9,49. Karena nilai chisquare hitung $=2.739<$ chisquaretabel $=9,49$. Dengan demikian $\mathrm{H}_{0}$ ditolak dan $\mathrm{Hi}_{\mathrm{i}}$ diterima yang berarti ada hubungan yang signifikan, dan terdapat hubungan tayangan imajinatif anak yang suka menolong di Taman Kanak-kanak Riyanti BTN tamarunang Kabupaten Gowa

2. Berdasarkan Hasil penelitian menunjukkan bahwa perilaku anak yang berjenis kelamin laki-laki berada pada tingkat tinggi sebanyak 10 anak, walaupun jumlah anak 
perempuan lebih besar dari jumlah anak laki-laki. Namun terlihat pada hasil penelitian bahwa pola komunikasi pada anaklaki-laki berada pada kategori tinggi dibandingkan dengan anak perempuan,yang berarti ada perbedaan perilaku anatara anak laki-laki dan anak perempuan.

\section{DAFTARPUSTAKA}

Al-Qur'andanTerjemahannya,

Bambang,Aa, KomunikasiMassa :Dalam Karakter Ilmu Komunikasi:JakartaEphsilon AlphaBetha,2000.

Bailey, Ronald H. Kekerasan Dan Agresi. Jakarta: TiraPustaka,1988. Bungin, Burhan.SosilogiKomunikasi. Jakarta: Kencana, 2009.

Cangara, Hafied.PengantarIlmu Komunikasi. Jakarta: PT RajaGrafindo Persada,2011.

Djamarah, SyaifulBahri. Pola Komunikasi Orang Tuadan Anakdalam KeluargaSebuah PerspektifPendidikan Islam.Jakarta: PT.Rineka Cipta, 2004.

Effendy, OnongUchjana. Kamus Komunikasi.Bandung: CV MandarMaju, 1989. Feldman, dkk.Human Development(PsikologiPerkembangan).Jakarta: Kencana,2008.

Haryatmoko, Etika Komunikasi, Manipulasi Media,Kekerasan Dan Pornografi.Kanisius. Yogya. 2007.

Hurlock, E.B. PerkembanganAnak Jilid 1. Alih BahasaIndonesia olehMetasariTjandrasa dan MuslichahZarkasih.Jakarta: Erlangga, 1978.

Kriyanto, Rachmat.Teknik Praktis Riset Komunikasi, Jakarta:Kencana PrenadaMedia, 2012.

Kuswandi, W. Komunikasi Massa. Jakarta: Rineka Cipta, 2008. McQuail, TeoriKomunikasi Massa. Jakarta: Salemba Humanika, 2011.

Mulyana,Dedy.Ilmu Komunikasi: SuatuPengantar. Bandung: PT RemajaRosdaKarya.2007.

Musbikin, imam.Dibesarkan kantong ajaibdoraemon.Jogjakarta: Diva Press, 2009. Nurudin.Sistem KomunikasiIndonesia. RajawaliPers, 2004. 
Tubbs, StewardL \&Syilvia M. Human Communication: Konteks-konteks Komunikasi, buku 2 terjemahan: DedyMulyana.Bandung: PT Remaja Rosdakarya,2000.

Singgih,Gunarsa.Dasardan TeoriPerkembangan Anak.Jakarta:PT.BPKGunungMulia, 1997.

Sobur,Alex.PsikologiUmum.Bandung: PustakaSetia, 2003.

Sugiyono.MetodePenelitianKuantitatif,Kualitatif,R\&D.Bandung:Alfabeta,2013.

-------StatistikUntuk Penelitian.Bandung:Alfabeta,2013.

Arini, dkk (2008),PengaruhTayangan Film Kartun Terhadap Pola Tingkah LakuAnakUsia SekolahDasar.

Malikhah2013, KorelasiPengaruh Tayangan TelevisiTerhadap PerkembanganPerilaku NegatifAnakUsia Dini. 